\title{
Geografi dalam Perspektif Filsafat Ilmu
}

\author{
Furqan Ishak Aksa ${ }^{1}$, Sugeng Utaya ${ }^{2}$, Syamsul Bachri ${ }^{2}$
}

${ }^{1}$ Program Studi Pendidikan Geografi, Universitas Samudra, Langsa.

${ }^{2} J u r u s a n$ Geografi Universitas Negeri Malang.

Korespondent E-mail: furqanishaksa@unsam.ac.id

Diterima: 2018-07-31 /Refisi:2019-02-04 Disetujui: 2019-03-21

(๑2019 Fakultas Geografi UGM dan Ikatan Geograf Indonesia (IGI)

\begin{abstract}
Abstrak Kecenderungan spesialisasi ilmu geografi semakin marak terjadi (khususnya di Indonesia). Geografi tidak lagi dimaknai sebagai suatu ilmu yang utuh meliputi fisik dan manusia. Hal ini berakibat pada kajian yang dilakukan oleh geograf hanya sampai pada ilmu bantu geografi. Tidak jarang justru beririsan dengan rumpun ilmu lain. Kondisi tersebut sangat tidak menguntungkan, geografi dapat dianggap bukan sebagai ilmu apabila tidak memiliki ciri khas/ pembeda dengan ilmu lain. Hal tersebut dapat mengancam eksistensi ilmu geografi di masa mendatang. Artikel ini ingin memberikan gambaran secara eksplisit kedudukan ilmu geografi dari perspektif filsafat ilmu. Dengan mengkaji berbagai literatur, tulisan ini mencoba menjelaskan aspek ontologi, epistimologi, dan aksiologi geografi. Secara ontologi geografi merupakan ilmu yang mengkaji aspek fisik dan sosial. Ciri khas kajian geografi menggunakan pendekatan utama yakni keruangan, kelingkungan, dan kompleks wilayah. Secara epistimologi geografi menggunakan metode kuantitatif serta kualitatif. Hal ini dikarenakan, dalam mengkaji aspek fisik dan manusia penggabungan kedua metode tersebut sangat disarankan sehingga hasil kajian geografi lebih komprehensif. Secara aksiologi keberadaan ilmu geografi semakin penting saat ini untuk mendukung pembangunan berkelanjutan.
\end{abstract}

Kata kunci: Geografi, Filsafat, Ontologi, Epistimologi, Aksiologi

\begin{abstract}
The propensity of geography specialization is increasingly prevalent (especially in Indonesia). Geography is no longer interpreted as integrative, covering both physical and human aspects. This resulted in a study by geographers concerning only material objects of geography. Not infrequently it would be overlapping with other science clusters. This condition is disadvantageous, geography can be considered not as a science if it does not have the characteristics/differentiation with other science. It may affect the existence of geography in the future. This article aims to provide the description of the geography from the perspective of philosophy of science. By reviewing the literature, this paper attempts to explain aspects of ontology, epistemology, and axiology. Ontology geography is a science that examines the physical and human aspects. Characteristic of geography study using spatial approach, environment, and area complex. Epistemologically, geography uses both quantitative and qualitative methods. Caused, in examining the physical and human aspects of using the two methods is highly recommended so that the results of geographic studies more comprehensive. As axiology the existence of geography is increasingly important to sustainable development goals.
\end{abstract}

Keywords: Geography, Philosophy, ontology, epistemology, axiology

\section{PENDAHULUAN}

Geografi merupakan ilmu yang sangat kompleks. Objek material geografi sangat luas (Arild HoltJensen, 2003). Hal ini terkadang membuat para geograf (khususnya di Indonesia) terjebak pada ilmu bantu geografi dan sering bersinggungan dengan rumpun ilmu lain (Suharsono \& Budi, 2006). Kondisi tersebut diperparah oleh semakin besarnya kecendurangan spesialisasi ilmu geografi yang meliputi geografi fisik, sosial dan teknik. Akibatnya geografi tidak lagi dimaknai sebagai suatu ilmu yang utuh. Kondisi tersebut membuat geografi terkesan tidak memiliki ciri khas dan termarginalkan (Yunus, 2008).

Selain itu, dalam konteks pendidikan geografi, fakta menunjukkan bahwa kondisi pembelajaran geografi yang berlangsung di sekolah Indonesia mulai tingkat dasar sampai menengah cenderung menghafal konsep (nama sungai, danau, negara, ibukota, dll). Hal ini terlihat dari buku teks yang beredar di pasaran dan digunakan oleh guru dan siswa dalam pembelajaran didominasi oleh fakta/data dan konsep (Aksa et al, 2018). Buku teks tersebut tidak mengarahkan siswa untuk berfikir kritis dan analitis. Hal ini membuat pembelajaran geografi yang berlangsung di sekolah menjadi tidak menarik bagi siswa.

Kondisi tersebut berbeda dengan di beberapa negara maju, misalnya di Amerika. Kurikulum geografi telah dirancang berbasis kehidupan (BEDNARZ, 2015). Kurikulum tersebut membekali siswa kompetensi - kompetensi dasar yang harus dikuasi untuk dapat diterapkan dalam kehidupan sehari - hari. Pembelajaran geografi yang berlangsung di sekolah pada hakikatnya membentuk geocapabilities (Uhlenwinkel et al , 2017). Kegiatan menghafal fakta dan konsep telah ditinggalkan. Siswa diarahkan untuk berfikir kritis dan analitis terhadap berbagai perbedaan dan persamaan 
geosfer di permukaan bumi (Bednarz, 2004).

Kesalahan - kesalahan dalam melakukan kajian fenomena geosfer dan membelajaran geografi kepada siswa, diduga karena para geograf Indonesia belum memahami secara utuh hakikat ilmu geografi. Kondisi tersebut sangat memprihatinkan, geografi dapat dianggap bukan sebagai ilmu karena tidak jelas objek kajiannya serta tidak penting untuk dipelajari. Kondisi tersebut dapat mengancam eksistensi ilmu geografi di Indonesia. Oleh karena itu, artikel ini ingin memberikan gambaran secara eksplisit kedudukan ilmu geografi dari perspektif filsafat ilmu. Dengan mengkaji berbagai literatur, tulisan ini mencoba menjelaskan aspek ontologi, epistimologi, dan aksiologi geografi sehingga memiliki alasan yang kuat untuk dikatakan sebagai ilmu.

\section{HASIL DAN PEMBAHASAN \\ Ontologi Geografi}

Ontologi merupakan cabang ilmu filsafat yang mengkaji hakikat sebenarnya suatu ilmu. Oleh karena itu, supaya para geograf Indonesia tidak terjebak pada kajian rumpun ilmu lain, kiranya perlu memahami kembali aspek ontologi filsafat ilmu geografi. Secara ontologi ilmu geografi harus dipahami secara utuh oleh para geograf. Hal ini dapat dilakukan dengan merujuk kembali pengertian - pengertian geografi yang dikemukakan oleh para ahli dan perhimpunan geografi.

Ada beragam definisi geografi yang berkembang saat ini, misalnya pendapat Hangget (1983) yang menyatakan bahwa Geography is an integrative discipline that brings together the physical and human dimensions of the world in the study of people, place, and environments. Selain itu, ada juga definisi geografi yang dirumuskan oleh para ahli geografi Indonesia pada Seminar dan Lokakarya di Semarang tahun 1988 yang menjelaskan bahwa geografi adalah ilmu pengetahuan yang mempelajari persamaan dan perbedaan fenomena geosfer dengan menggunakan sudut pandang kelingkungan \& kewilayahan dalam konteks keruangan.

Dari definisi tersebut, secara eksplisit dapat dipahami bahwa geografi merupakan bidang ilmu yang integratif antara aspek fisik dan sosial. Dalam mengkaji fenomena geosfer tidak boleh hanya menyentuh aspek fisik saja. Kajian geosfer harus komprehensif meliputi aspek fisik dan sosial (manusia). Selain itu, ilmu geografi merupakan analisa sintesis terhadap fenomena geosfer (Arild Holt-Jensen, 2003; Haggett, 1983). Dalam melakukan kajian geosfer, seorang geograf harus menggunakan tiga pendekatan utama yaitu keruangan, kelingkungan, dan kompleks wilayah. Tiga pendekatan tersebut merupakan ciri khas geografi yang tidak dimiliki oleh ilmu lain.

Pendekatan keruangan menekankan pada analisa sintesis terhadap variasi perbedaan lokasi di permukaan bumi serta faktor-faktor apa yang dominan mempengaruhi perbedaan tersebut. Kemudian, pendekatan kelingkungan menekankan pada hubungan (interaksi) antara manusia dengan lingkungan (alam). Sementara itu, pendekatan kompleks wilayah adalah penggabungan antara keruangan dan kelingkungan. Analisis kompleks wilayah menekankan pada kajian komprehensifterhadap suatu wilayah meliputiaspekfisik dan manusia (Arild Holt-Jensen, 2003; Haggett, 1983).

Dalam melakukan analisis terhadap fenomena geosfer, penggunaan ketiga pendekatan tersebut disesuaikan dengan topik (tema) kajian. Misalnya dalam kajian geografi bencana, penggunaan pendekatan keruangan menekankan pada kajian tentang perbedaan variasi jenis bencana (Mönter \& Otto, 2017), contohnya mengapa Pulau Sumatra memiliki indeks risiko gempa bumi sangat tinggi dibandingkan dengan Palau Kalimantan. Dalam hal ini, kajian tersebut harus menyajikan faktor yang dominan mempengaruhi perbedaan jenis bencana antara satu wilayah dengan lainnya.

Kemudian, dengan menggunakan pendekatan kelingkungan, kajian fenomena geosfer menekankan pada peran manusia (interaksi manusia dengan lingkungan). Dalam konteks geografi bencana, geograf harus mengkaji secara eksplisit peran manusia terhadap permasalahan lingkungan yang terjadi saat ini yang mengakibatkan terjadinya bencana. Misalnya, tingginya indeks risiko bencana hidrometeorologis yang terjadi saat ini tidak terlepas dari aktivitas manusia dalam mengeksploitasi sumber daya alam secara berlebihan yang berdampak pada kerusakan lingkungan (Chang \& Pascua, 2016). Selain itu, penggunaan energi fosil yang berlebihan berdampak pada perubahan iklim (Shaw, Mallick, \& Takeuchi, 2011).

Selanjutnya, pendekatan kompleks wilayah dalam kajian geografi bencana menekankan pada penilaian indeks risiko bencana. Dalam melakukan analisis risiko bencana, geograf harus mengkaji aspek fisik dan sosial secara komprehensif (Mönter \& Otto, 2017). Gambaran umum integrasi aspek fisik dan sosial dalam kajian geografi bencana dapat dilihat pada gambar 1 .

Dari gambar 1 tersebut dapat dipahami bahwa kajian bencana dari prespektif geografi tidak bisa dipisahkan antara aspek fisik dan sosial. Pendapat tersebut menguatkan bahwa sebagai suatu ilmu yang utuh, geografi tidak bisa dipisahkan antara sosial dan fisik (Arild Holt-Jensen, 2003). Oleh karena itu, berdasarkan pembahasan tersebut, spesialisasi geografi yang saat ini banyak terjadi serta pembelajaran geografi yang berlangsung di sekolah saat ini yang menekankan pada aspek hafalan dan pemahaman tidak sesuai dengan kaidah keilmuan geografi serta tidak memiliki landasan filosofi. Secara ontologi, geografi merupakan ilmu yang integratif mengkaji aspek fisik dan sosial.

\section{Epistimologi Geografi}

Epistimologi merupakan cabang filsafat yang menekankan pada kajian terhadap cara mendapatkan pengetahuan secara benar. Dalam hal ini, aspek epistimologi dalam ilmu geografi sama seperti rumpun 


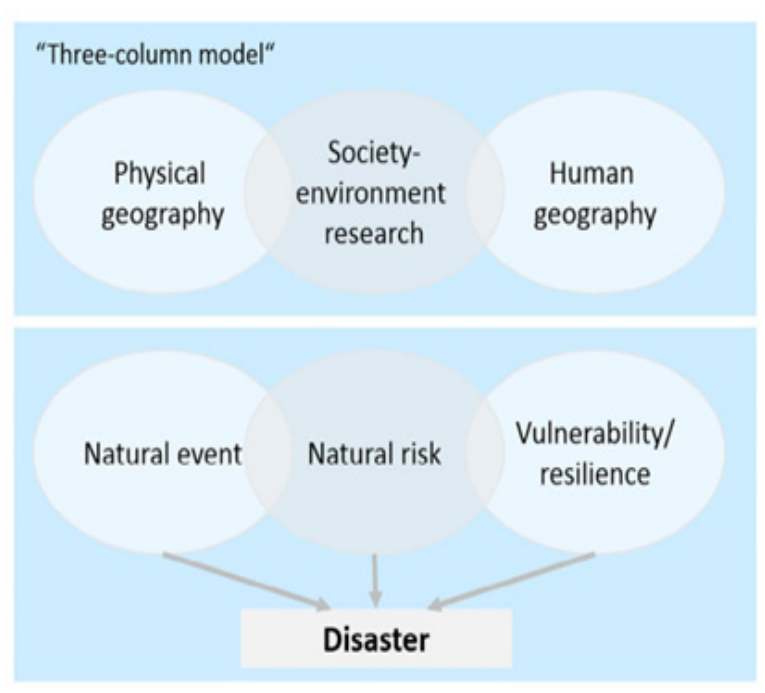

Gambar 1 Model Kajian dalam geografi bencana Sumber: Mönter \& Otto (2017)

ilmu lainnya yakni menggunakan metode induktif dan deduktif. Hal ini bertujuan untuk mendapatkan data yang komprehensif terhadap kajian fenomena geosfer.

Selain itu, epistimologi geografi juga menggunakan analisa kuantitif dan kualitatif. Teknik analisis kuantitatif dalam kajian geografi berkembang pesat pada pertengahan abad 20 ketika terjadi revolusi kuantitatif (Yunus, 2008). Saat itu, sebagian besar kajian geografi menggunakan analisa kuantitaf. Namun demikian, seiring dengan berkembangnya paradigma keilmuan geografi, para geograf menyakini bahwa analisa kuantitatif dalam kajian geografi belum mampu memuaskan serta menyelesaikan dan menjawab permasalahan geografi yang muncul. Hal ini dikarenakan sebagai ilmu yang mengkaji aspek alam dan manusia, kajian geografi tidak cukup hanya menggunakan analisa kuantitatif. Oleh karena itu, perlu juga dianalisis secara kualitatif.

Saat ini, para geograf menyakini bahwa dengan menggunakan metode induktif dan deduktif serta analisis kuantitatif serta kualitatif, kajian terhadap permasalahan alam yang termasuk dalam kajian geografi semakin komprehensif. Setiap permasalahan yang dikaji memberikan hasil yang bermanfaat bagi perkembangan ilmu pengetahuan dewasa ini. Dengan menggunakan metode tersebut hasil penelitian geografi memberikan ciri khas tersendiri yang membedakan dengan ilmu lain. Salah satu contohnya dalam mengkaji gunung berapi, para geograf dapat menggunakan analisa kuantitatif dengan memanfaatkan teknologi geospatial untuk memetakan area terdampak. Hasil analisa tersebut memberikan manfaat kepada stakeholders dalam pengambilan keputusan.

Selain itu, dengan analisa kualitatif, kajian gunung berapi juga mengkaji aspek aktivitas manusia yang berada di sekitar gunung berapi. Meletusnya gunung berapi tentu tidak hanya berdampak negatif terhadap kehidupan masyarakat di sekitar lereng pengunungan.
Namun, turut memberikan berkah bagi masyarakat sekitar. Material gunung berapi dapat dimanfaatkan oleh masyarakat sebagai material bagunan serta pada masa tertentu akan membuat tanah menjadi subur.

Disamping itu, kawasan gunung berapi menjadi destinasi wisata yang dapat menghidupkan ekonomi masyarakat sekitar. Hal tersebut yang menjadi salah satu faktor sulitnya melakukan relokasi pemukiman penduduk yang dekat dengan area gunung berapi. Oleh karena itu, hasil kajian komprehensif tersebut menjadi penting untuk dipertimbangkan oleh stakeholders dalam melakukan evakuasi perumahan warga.

\section{Aksiologi Geografi}

Geografi masih eksis hingga saat ini dikarenakan masih memberikan kebermanfaatan bagi pengembangan ilmu pengetahuan dan teknologi. Sejak awal munculnya, ilmu geografi telah memberikan manfaat bagi manusia dalam melakukan penjelajahan dunia. Salah satunya adalah peran dari ahli geografi muslim dunia pada abad ke 12 yang bernama Al Idrisi. Ia membuat peta dunia pertama yang dilengkapi dengan jalur perdagangan, sungai, daratan, dan pegunungan. Peta dunia tersebut memberikan manfaat kepada penjelajah dunia seperti Cristhoper Columbus yang menemukan benua Amerika.

Di samping itu, akibat dari eksploitasi sumber daya alam serta penggunaan energi fosil secara besar - besar ketika revolusi industri telah berdampak pada kerusakan lingkungan. Kondisi tersebut menyebabkan terjadinya pemanasan global serta bencana hidromoteorologis. Keberadaan ilmu geografi semakin penting untuk mendukung pembangunan berkelanjutan (Sprenger \& Nienaber, 2017). Pendekatan kelingkungan yang menjadisalah satu cirikhas geografi semakin dibutuhkan untuk melakukan kajian - kajian terhadap kerusakan lingkungan yang terjadi saat ini. Dalam hal ini, peran manusia sangat dominan. Oleh karena itu, geografi memiliki peran besar untuk melakukan kajian tersebut.

Selain itu, di negara maju seperti Amerika. Geografi telahmenjadimata pelajaran pokokdan wajib daritingkat dasar hingga perguruan tinggi. Mereka telah menyadari bahwa pendidikan merupakan sarana yang tepat untuk membentuk sikap siswa peduli terhadap lingkungan sehingga dapat berperan dalam menyelamatkan bumi dari ancaman bencana (Sprenger \& Nienaber, 2017). Saat ini, Asosiasi Pendidikan Geografi Amerika telah merumuskan geocapablities yang harus dikuasi siswa dalam mempelajari geografi, meliputi: kemampuan imajinasi geografi, menumbuhkan sikap etis, berfikir integratif dengan lingkungan, berfikir spatial, dan mengeksplorasi tempat (Walkington et al, 2017).

Kemampuan imajinasi geografi merupakan kemampuan dalam memaknai perbedaan variasi lokasi di permukaan bumi. Sementara itu, menumbuhkan sikap etis tercermin dari sikap peduli terhadap bangsa (nasionalisme) serta mampu menghargai perbedaan budaya disetiap wilayah. Kemudian, kemampuan 
berfikir integratif dengan lingkungan menuntut siswa memahami interaksi antara manusia dengan lingkungan. Dalam hal ini, peran manusia sangat penting dalam menjaga kelestarian lingkungan (Chang \& Pascua, 2016; Mitchell, Borden, \& Schmidtlein, 2008).

Selanjutnya, kemampuan berfikir spasial sangat penting dikuasai oleh siswa guna mendeskripsikan berbagai fenomena alam di permukaan bumi (Gersmehl, 2008; Lee \& Bednarz, 2012). Dalam melihat suatu fenomena geosfer yang terjadi di permukaan bumi, pemahaman siswa bukan hanya apa dan dimana, melainkan mengapa fenomena tersebut terjadi di wilayah itu (Arild Holt-Jensen, 2003). Kemudian, kemampuan mengeksplorasi tempat menuntut siswa untuk dapat menganalisis dan memahami karakteristik berbagai tempat di permukaan bumi dengan menggunakan konsep ruang, skala, dan interkoneksi (Uhlenwinkel et al., 2017).

\section{KESIMPULAN}

Geografi merupakan ilmu yang sangat menarik untuk dipelajari. Pada hakikatnya belajar geografi lebih menekankan pada cara unik untuk mempelajari bumi dengan berbagai ilmu bantu dalam persepktif geography eye (sudut pandang geografi meliputi: keruangan, kelingkungan, dan kompleks wilayah). Hal ini yang menjadi kekuatan ilmu geografi yang tidak dimiliki oleh ilmu lain. Oleh karena itu, sudah saatnya para geograf untuk kembali ke landasan filosofi tersebut. Spesialisasi yang terlalu jauh jusrtu membuat ilmu geografi semakin kabur dan tidak jelas serta bersinggungan dengan ilmu lain. Kondisi tersebut sangat tidak menguntungkan bagi geograf.

Sudah sepatutnya, bagi ilmuan geografi untuk memengang teguh tiga pendekatan utama geografi tersebut dalam kajian berbagai isu. Dengan menggunakan metode kuantitatif dan kualitatif dari aspek epistimologi geografi, penulis menyakini hasil penelitian dan kajian yang dilakukan akan semakin menarik dan komprehensif. Hasil penelitian tersebut akan menjadi masukan berharga bagi stakeholders.

Kemudian, dalam konteks pendidikan geografi, sudah saatnya kurikulum geografi di Indonesia direvisi dan disempurnakan. Kurikulum geografi kedepan harus memiliki standar yang jelas serta berbasis Higher Order Thinking Skill (HOTS). Kompetensi dasar yang dirumuskanharusdapatmerangsangsiswauntukberfikir kiritis dan analisis. Selain itu, muatan konten dalam silabus lebih menekankan pada kehidupan sehari - hari siswa. Pembelajaran geografi harus membekali siswa kompetensi yang dapat diterapkan pada kehidupannya, misalnya geocapabilities dan Geography for Life yang telah diterapkan di Amerika (Butt \& Lambert, 2014).

\section{UCAPAN TERIMA KASIH}

Artikel ini merupakan bagian dari disertasi penulis pertama. Oleh karena itu, penulis mengucapkan terima kasih kepada Prof. Dr. Sugeng Utaya,
M.Si dan Syamsul Bachri, M.Sc, PhD yang telah memberikan banyak masukan dalam penulisan artkel ini serta telah memberikan wawasan sangat penting tentang landasan filsafat geografi.

\section{DAFTAR PUSTAKA}

Aksa, F, I, Afrian, R, \& Jofrishal. (2018). Analisis Konten Buku Teks Geografi SMA Menggunakan Model Beck \& Mckeown. Jurnal Pendidikan Geografi, 23(1), 1-8. http://dx.doi.org/10.17977/um017v23i12018p001

Arild Holt-Jensen. (2003). Geography History \& Concepts. London: Sage Publications.

Bednarz, S. W. (2004). US World Geography Textbooks: Their Role in Education Reform. International Research in Geographical and Environmental Education, 13(3), 223-238. https://doi.org/10.1080/10382040408668517

BEDNARZ, S. W. (2015). Setting the Standard for Standards: Perspectives on Standard Setting in the United States. Coğrafya Eğitimi Dergisi [Turkish Journal of Geography Education], 1(2), 3-9.

Butt, G., \& Lambert, D. (2014). International perspectives on the future of geography education: an analysis of national curricula and standards. International Research in Geographical and Environmental Education, 23(1), 1-12. https://doi.org/10.1080/10382046.2013.858402

Chang, C.-H., \& Pascua, L. (2016). Singapore students' misconceptions of climate change. International Research in Geographical and Environmental Education, 25(1), 84-96. https://doi.org/10.1080/10382046.2015.1106206 Gersmehl, P. (2008). Teaching geography (Third edition). New York: The Guilford Press.

Haggett. (1983). Geography: A Modern Synthesis. New York: Harper \& Row.

Lee, J., \& Bednarz, R. (2012). Components of Spatial Thinking: Evidence from a Spatial Thinking Ability Test. Journal of Geography, 111(1), 15-26. https://doi.org/10.1080/00221341.2011.583262

Mitchell, J. T., Borden, K. A., \& Schmidtlein, M. C. (2008). Teaching Hazards Geography and Geographic Information Systems: A Middle School Level Experience. International Research in Geographical and Environmental Education, 17(2), 170-188. https://doi.org/10.1080/10382040802148679

Mönter, L., \& Otto, K.-H. (2017). The concept of disasters in Geography Education. Journal of Geography in Higher Education, 1-15. https:// doi.org/10.1080/03098265.2017.1339266

Shaw, R., Mallick, F., \& Takeuchi, Y. (2011). Chapter 5 Essentials of Higher Education in Disaster Risk Reduction: Prospects and Challenges. In R. Shaw, K. Shiwaku, \& Y. Takeuchi (Eds.), Community, Environment and Disaster Risk Management (Vol. 7, pp. 95-113). Emerald Group Publishing Limited. https://doi.org/10.1108/S2040-7262(2011)0000007011

Sprenger, S., \& Nienaber, B. (2017). (Education for) Sustainable Development in Geography Education: review and outlook from a perspective of Germany. Journal of Geography in Higher Education, 1-17. https://doi.org/10.1080/03098265.2017.1379057 Suharsono, S., \& Budi, T. P. (2006). Penajaman Dan Kejelasan Objek Kajian Dalam Disiplin Ilmu Geografi. Majalah Geografi Indonesia, 20(2), 187-201. Uhlenwinkel, A., Béneker, T., Bladh, G., Tani, S., \& Lambert, D. (2017). GeoCapabilities and curriculum leadership: 
balancing the priorities of aim-based and knowledge-led curriculum thinking in schools. International Research in Geographical and Environmental Education, 26(4), 327341. https://doi.org/10.1080/10382046.2016.1262603

Walkington, H., Dyer, S., Solem, M., Haigh, M., \& Waddington, S. (2017). A capabilities approach to higher education: geocapabilities and implications for geography curricula. Journal of Geography in Higher Education, 1-18. https://doi.org/10.1080/03098265.2017.1379060

Yunus, Hadi, Sabari. (2008). Konsep dan Pendekatan Geografi. Makalah dipresentasikan dalam Serasehan Forum Pimpinan Pendidikan Tinggi Geografi Indonesia 18 dan 19 Januari. 